\title{
Microvascular Anatomy of Olfactory and Accessory Olfactory (Vomeronasal) Organs in Adult Xenopus laevis: Scanning Electron Microscopy of Vascular Corrosion Casts
}

\author{
Anatomía Microvascular de Órganos Olfatorios y Accesorios (Vomeronasal) en Adultos \\ Xenopus laevis: Microscopía Electrónica de Barrido de Moldes de Corrosión Vascular
}

Lametschwandtner, A. \& Minnich, B.

LAMETSCHWANDTNER, A. \& MINNICH, B. Microvascular anatomy of olfactory and accessory olfactory (vomeronasal) organs in adult Xenopus laevis: Scanning electron microscopy of vascular corrosion casts. Int. J. Morphol., 36(3):1007-1015, 2018

SUMMARY: Microvascular anatomy and histomorphology of olfactory and vomeronasal organs in adult Xenopus laevis Daudin were studied by scanning electron microscopy of vascular corrosion casts and paraplast embedded stained serial tissue sections. Results show that the arterial supply is bilaterally by terminal arterioles of the medial branch of the nasal artery and by the palatal artery. Arterioles give rise to a capillary meshwork characteristic for respiratory surfaces in principal chambers and in dorsal and caudal areas of middle chambers. Anterior and inferior areas of the middle chambers own a distinctly different capillary network with conspicuous short capillary loops. Loops have a dilated tip and extend in acute angles towards the chamber lumen. The vomeronasal organ (VNO) locates beneath the olfactory organ. It has a medial to lateral extension and attaches with its caudal circumference to the medial nasal glands. Its capillary bed displays rectangular meshes which preferentially orientate along the long axis of the VNO. Locally, capillaries form short hairpin-like or strongly twisted loops with dilated tips which point towards the lumen of the VNO. These capillaries slow-down blood velocity and may lead to an increased exchange of oxygen, nutrients and water-borne odorants in the middle chambers and of pheromones in the VNO. In the latter vascular structures are present which might serve as a vascular pump.

KEY WORDS: Xenopus; Olfactory organs; Microvasculature; Vascular corrosion casts; Scanning electron microscopy.

\section{INTRODUCTION}

Main (MOS) and accessory olfactory systems (AOS) of vertebrates are well studied. Little attention, however, is paid to their microvascular anatomy. In some mammals vasomotor pumping mechanisms are discussed as being involved in the influx and efflux of odorants/pheromones loaden fluids of the vomeronasal organ (VNO) (Meredith \& O Connell, 1979; Meredith et al., 1980; Eccles, 1982; Salazar et al., 1997, 2008; Salazar \& Sánchez Quinteiro, 1998; Jermakowicz et al., 2004; Wang et al., 2008; Nowack \& Wöhrmann-Repenning, 2009; Královec et al., 2013). In the tammar wallaby this mechanism is described as "..to be achieved through dilatation and contraction of two large blood vessels on opposite sides of the VNO through pulsation of the blood or regulation of the blood supply" (Schneider et al., 2008). A similar mechanism is described in the cow (Salazar et al., 2008) and in the giraffe, whereby in the giraffe a specific secondary pump consisting of numerous thinwalled vessels located immediately beneath the epithelia is described (Kondoh et al., 2017).
Amphibia are exposed to air- and water-borne odorants and pheromones. In Xenopus, ontogeny of olfactory and accessory olfactory (vomeronasal) organs (Quinzio \& Reiss, 2018), anatomy (Föske, 1934; Altner, 1962), fine structure of olfactory neuroepithelia of nasal chambers (Oikawa et al., 1998), olfactory receptors (Freitag et al., 1995; Suzuki et al., 1999), neuroepithelial axonal projections to the main olfactory bulb, and vomeronasal pathways to the accessory olfactory bulb (Saito \& Taniguchi, 2000) are described in great detail. However, only Suzuki et al. referred to the blood vessels and demonstrated by light microscopy of stained tissue sections that in Xenopus more developed "vasoganglions" (an obsolete term for a mass or aggregate of blood vessels; Segen's Medical Dictionary. ( 2012 Farlex, Inc.) are found at the base of epithelia of middle chambers than at those of principal chambers. As the authors did not reconstruct the spatial arrangement of these "vasoganglions" there is no knowledge about the microvascular anatomy of these organs. To gain a detailed view of the spatial 
arrangement of the blood vessels in these organs and to explore whether the vascular anatomy is part of a pumping mechanism similar to that described in some mammals (see above) we here analyze vascular corrosion casts of the adult pipid frog, Xenopus laevis Daudin by scanning electron microscopy (SEM) (Murakami, 1971; Lametschwandtner et al., 1990; Aharinejad \& Lametschwandtner, 1992; Motta et al., 1992) and correlate SEM results with histomorphological findings from stained serial tissue sections.

\section{MATERIAL AND METHOD}

Animals. Eight adult African Clawed Toads, Xenopus laevis Daudin (body weights: 18.9 - 78.8 g; snout-vent lengths: 60 - $90 \mathrm{~mm}$ ) were studied. Adults were housed in aquaria (tap water depth: $15 \mathrm{~cm}$ ) equipped with aquarium filters and fed twice a week with either dried Gammarus pulex or grinded beef heart.

Histomorphology. To enable a correlation of vascular corrosion casts with olfactory organs' anatomy and morphology one adult female (body weight: 78.8 grams, snout-vent length: $90 \mathrm{~mm}$ ) and one male Xenopus (body weight: 78 grams; snout-vent length: $70 \mathrm{~mm}$ ) were killed by immersion within an overdose of MS 222 (0.5\%; Aldrich Chemicals, St. Louis, US). After measuring and weighing, the animals were pinned in supine position onto a wax plate. The heart with bulbus cordis and truncus arteriosus was exposed by thoracotomy and a ligature was placed around the bulbus cordis. Next, the ventricle was cut open and a blunt grinded vein flow G19 (Braun, Melsungen, FRG) guided by a micromanipulator was inserted through the opened ventricle into the truncus arteriosus. Subsequently, the blunted needle was tied in place with a ligature from thread to ensure its stability during the adjacent rinsing and fixing processes. Finally, the sinus venosus was cut open to allow efflux of blood and rinsing with amphibian ringer solution (Adam \& Czihak, 1964) was started. The flow rate of the infusion pump (Habel, Vienna) was set to $40 \mathrm{ml} / \mathrm{h}$. When clear reflux drained from the opened venous sinus fixation with $10 \mathrm{ml}$ Bouin's solution (Adam \& Czihak) was started using the same flow rate. The fixed upper jaw was excised, separated into a left and right half, dehydrated, and embedded in paraplast. One series of $7 \mu \mathrm{m}$ thick transverse and one of longitudinal sections were stained according to Goldner (Adam \& Czihak). Tissue sections were analyzed with an Olympus X51 microscope. Images were recorded by a Color View III digital camera (Soft Imaging Systems, FRG). If necessary brightness and contrast of images and background of sections were adjusted using Photoshop CS5 (Adobe Inc., Redwood, CA).
Vascular corrosion casting. After clear reflux from the opened venous sinus $10 \mathrm{ml}$ of Mercox CL-2B (Dainippon Ink and Chemicals, Tokyo, Japan; Ladd Burlington, Vermont, USA) diluted with monomeric methylmethacrylate $(4+1$, $\mathrm{v}+\mathrm{v}, 10 \mathrm{ml}$ monomeric methylacrylate contained $0.85 \mathrm{~g}$ initiator paste MA) were injected at a flow rate of $41 \mathrm{ml} / \mathrm{h}$ in six female Xenopus using an infusor pump (Fa. Habel, Vienna). When the effluent resin became viscous or the whole amount of resin had been perfused, the injection was stopped and the animals were left for $30 \mathrm{~min}$ at room temperature to allow hardening of the injected resin. Animals were then put into a water-bath $\left(60^{\circ} \mathrm{C} ; 12\right.$ - $\left.24 \mathrm{~h}\right)$ to temper the injected resin. Next, specimens were macerated in potassium hydroxide $\left(7.5 \% ; 40{ }^{\circ} \mathrm{C} ; 2-24 \mathrm{~h}\right)$, rinsed three times in distilled water, submerged in $2 \%$ hydrochloric acid, rinsed three times in distilled water followed by submersion in formic acid $\left(5 \% ; 20^{\circ} \mathrm{C} ; 5-15 \mathrm{~min}\right)$ to dissolve any residual organic matter adhering to the cast surfaces. Finally, specimens were rinsed another three times in distilled water and frozen in fresh distilled water. Ice-embedded casts were freeze-dried in a Lyovac GT2 (Leybold-Heraeus, Cologne, FRG). Upper jaws were excised and mounted onto specimen stubs using the "conductive bridge-method" (Lametschwandtner et al., 1980), either evaporated with carbon and gold and/or sputter-coated with gold, and examined in the scanning electron microscope XL-30 (FEI, Eindhoven, NL) at an accelerating voltage of $10 \mathrm{kV}$. After inspection of the vascular bed of the external nares specimens were de-mounted and re-mounted upside-down to inspect the internal nares vascular patterns. In some specimens course, branching patterns and areas of supply (or drainage) of individual vessels were exposed by ripping-off overlaying vessels under binocular control by fine tipped insect pins.

\section{RESULTS}

Histomorphology. Olfactory and vomeronasal organs lie bilaterally within the olfactory capsules (Fig. 1a,b). They consist of principal, middle and inferior chambers. The principal chambers are the largest ones. They extend from the external to the internal nares and communicate with the middle (Fig. 1b) and the inferior chambers (not shown). They own a ciliated columnar epithelium with abundant alveolar mucous glands (Bowman`s gland) embedded deeply in the subepithelial connective tissue. The middle chamber displays the most complex shape and extends with its cavities from a level rostral to the principal chamber towards caudally (Fig. 1b). Olfactory and accessory olfactory nerve bundles depart from the olfactory epithelia of principal and middle chambers respectively from the vomeronasal organs (Fig. 1a). An anterior group of medial nasal glands lies at the ventral wall of 

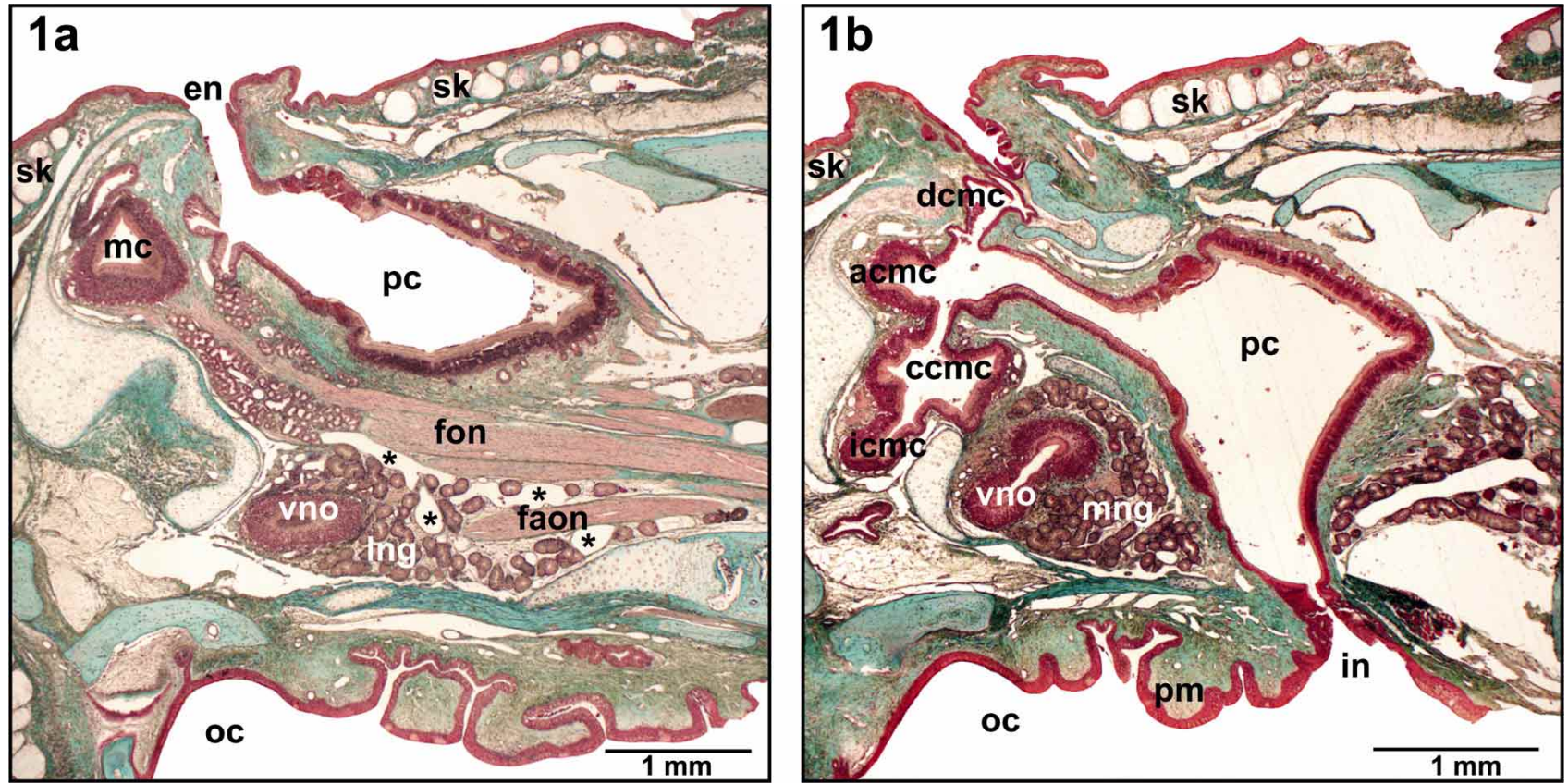

Fig. 1. Location and histomorphology of olfactory and accessory olfactory (vomeronasal) organs in adult Xenopus laevis. Longitudinal sections $(7 \mu \mathrm{m})$. Paraplast embedding. Goldner staining. Sections are from lateral (a) to medial (b). Anterior is to the left, dorsal is at top. Note wide vessels (asterisks) between and around nasal glands, olfactory and accessory olfactory nerve fiber bundles. acmc anterior cavity of middle chamber, ccmc caudal cavity of middle chamber, dcmc dorsal cavity of middle chamber, en external naris, faon fibers of accessory olfactory nerve, fon fibers of olfactory nerve, icmc inferior cavity of middle chamber, in inner naris, lng lateral nasal gland, mc middle chamber, mng medial nasal gland, oc oral cavity, pm palatal mucosa, pc principal chamber, sk skin, vno vomeronasal organ.

the principal chamber, a posterior group attaches to the caudal margin of the vomeronasal organ (Fig. 1). Large caliber vessels, both arteries and veins, are found embedded between olfactory and accessory olfactory nerve bundles and nasal glands (Fig. 1a, asterisks).

Gross arterial supply and venous drainage. The arterial supply of olfactory and accessory olfactory (vomeronasal) organs is bilaterally via the nasal artery (Fig. 2) and the palatine artery (Fig. 3). The nasal artery branches off the orbito-nasal artery, which is a branch of the occipital artery. It is the main supply of the olfactory organs (Fig. 2). The palatine artery arises from the internal carotid artery and supplies the palatal mucosa around the internal nares by terminal branches (Fig. 3 ). The caliber of the nasal artery is about twice that of the palatine artery (compare Figs. 2 and 3).

The nasal artery approaches the dorsal surface of the olfactory nerve at its anterior third (Fig. 2), penetrates, and courses between olfactory nerve bundles towards rostral (Fig. 4). On its course it issues branches which supply the dorsal wall of the principal chamber (Fig. 2), the capillary bed of olfactory and accessory olfactory nerve fiber bundles, and the posterior group of medial nasal glands (Fig. 4; see also Fig. 1a). Within the posterior group of medial nasal glands the nasal artery bifurcates into a medial and a lateral branch (Fig. 4). The medial branch first issues branches which supply the ventral wall of the principal chamber and medial areas of the vomeronasal organ (Figs. 4 and 5). Next it issues branches which feed the vomeronasal organ and the anterior group of medial nasal glands (Figs. 4 and 5). It then splits into several terminal branches which supply rostromedial areas of the principal chamber and the ventral, anterior and lateral walls of anterior, dorsal, caudal and inferior cavities of the middle chamber (Figs. 4 and 5).

Olfactory and vomeronasal organs drain via (i) the nasal veins (dorsal and medial walls of the principal chamber, and (ii) the anterior orbital veins (lateral and latero-ventral walls of the principal chamber; walls of the middle chamber) which join to form the orbito-nasal veins (Figs. 2 and 3). The orbital veins merge with the ophthalmic veins.

\section{Microvasculature}

Principal chambers. The subepithelial capillary beds of principal chambers show irregularly shaped meshes with no preferred orientation (Figs. 2, 4, 6 and 7). At the latero-ventral area rostro-caudally orientated densely packed capillaries outline the ventral fold (Figs. 2, 6 and 7). 

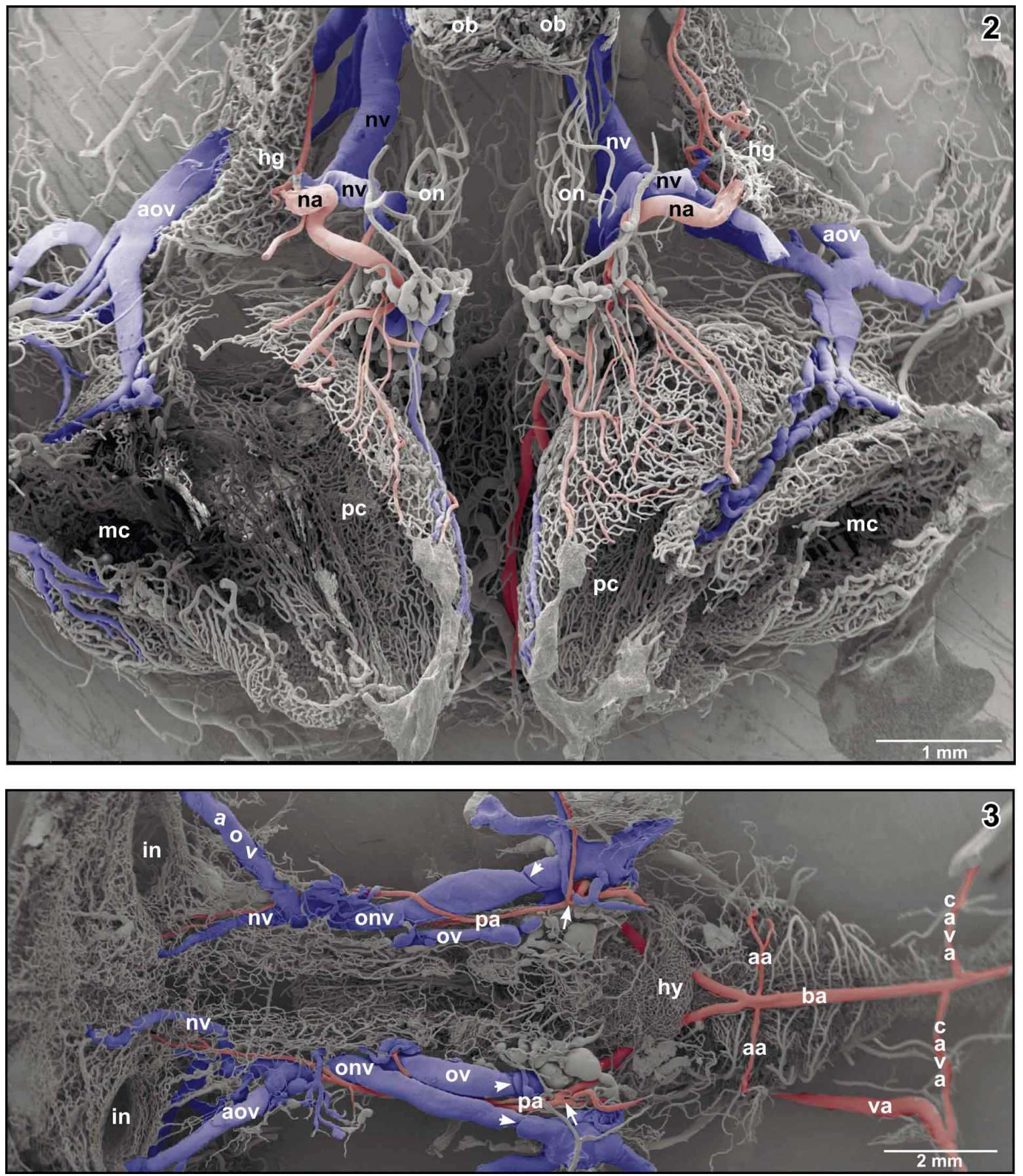

Fig. 2. Arterial supply and venous drainage of olfactory organs. Vascular corrosion cast. Dorsal view. Scanning electron micrograph. Rostral is at bottom. Arteries are red, veins are blue. The vascular beds around external nares and dorso-lateral wall of middle chamber (left olfactory organ) and principal chamber (right olfactory organ) are removed. aov anterior orbital vein, hg Haderian gland, mc middle chamber, na nasal artery, nv nasal vein, ob olfactory bulb, on olfactory nerve, pc principal chamber.

Fig. 3. Arterial supply and venous drainage of olfactory and vomeronasal organs. Vascular corrosion cast. Ventral view. Scanning electron micrograph. Rostral is to the left. Vascular bed of the palatal mucosa is partially removed to expose the course of the palatine artery (pa). Note origin of the thin palatine arteries (arrows) and venous valves (arrowheads). aa auditory artery, aov anterior orbital vein, ba basilar artery, cava communicating artery with vertebral artery, hy hypophysis, in internal naris (choana), nv nasal vein, onv orbitonasal vein, ov ophthalmic vein, va vertebral artery. 


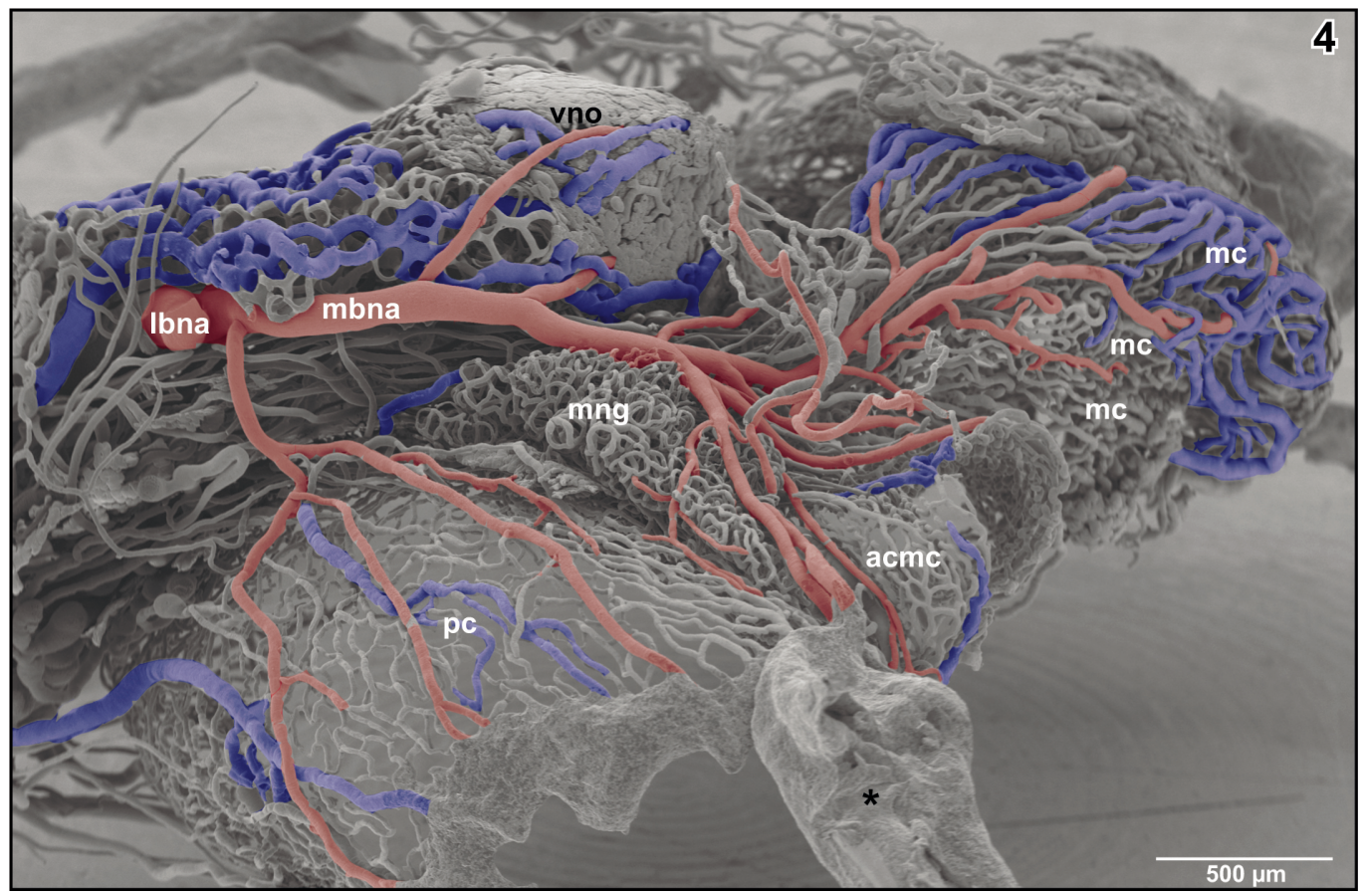

Fig. 4. Arterial supply of ventral walls of principal chamber (pc), middle chamber (mc) and vomeronasal organ (vno) by branches of the medial branch of the nasal artery (mbna). Anterior is to the right, lateral is at the top. acmc anterior cavity of middle chamber, lbna lateral branch of nasal artery, mng medial nasal glands. Asterisk marks conductive bridge.

Middle chambers. Middle chambers consist of anterior, dorsal, caudal and inferior cavities and communicate via a slit with the ipsilateral principal chambers (Fig. 7). While dorsal and caudal cavities own capillary meshes similar to those of principal chambers anterior and inferior cavities reveal a very different capillary bed (Fig. 8). Anterior cavities show a wide-meshed capillary network at their medial walls (Fig. 8) whereas their ventral and lateral walls as well as the walls of inferior cavities show a preferred anterior-posterior course of capillaries. Capillaries form short luminally directed ascending and descending loops in about acute angles to the surface of the cavities (Fig. 8). Tips of the capillary loops are widened (Fig. 8). Few arterioles only supply the capillary beds (Fig. 8, inset).

The vomeronasal organ (VNO). The vomeronasal organ which locates beneath and communicates with the ipsilateral principal chamber has a transverse orientation. Its caudal circumference contacts the anterior margin of the posterior group of medial nasal glands (Fig. 5). Laterally directed branches of the medial branch of the nasal artery supply from medially and from anteriorly (Figs. 5, 9 and 10). In the lateral area arterioles form slender rectangular capillary meshes orientated predominantly along the long axis of the VNO (Fig. 5). Locally, short capillary loops extend towards the lumen of the VNO. Capillary loops are either simple hair-pin like loops with a dilated tip or are intertwisted to a varying degree (Figs. 10-12). Arterio-venous transition distances are short. Postcapillary venules drain caudally into veins of the posterior group of the medial nasal glands (Figs. $4,5,10$ and 11) which drain via parallel running large veins into the nasal vein. These veins interconnect via conspicuously short capillary loops (Figs. 13 and 14).

\section{DISCUSSION}

Until now little attention has been paid to the microvascular anatomy of amphibian olfactory and vomeronasal organs. Only Suzuki et al. pointed at the presence of "vasoganglions" at the base of the olfactory epithelium of the anterior and inferior cavities of the medial chamber, but do not demonstrate any details. Our scanning electron micrographs convincingly demonstrate that these "vasoganglions" represent densely packed short capillary loops which orientate in an acute angle to the epithelia. As these capillary loops own dilated tips they most likely slow-down blood velocity and allow for an increased delivery of oxygen and nutrients to and an increased removal of metabolites from the olfactory epithelia of anterior and inferior cavities of the middle chambers and of the vomeronasal organs. 

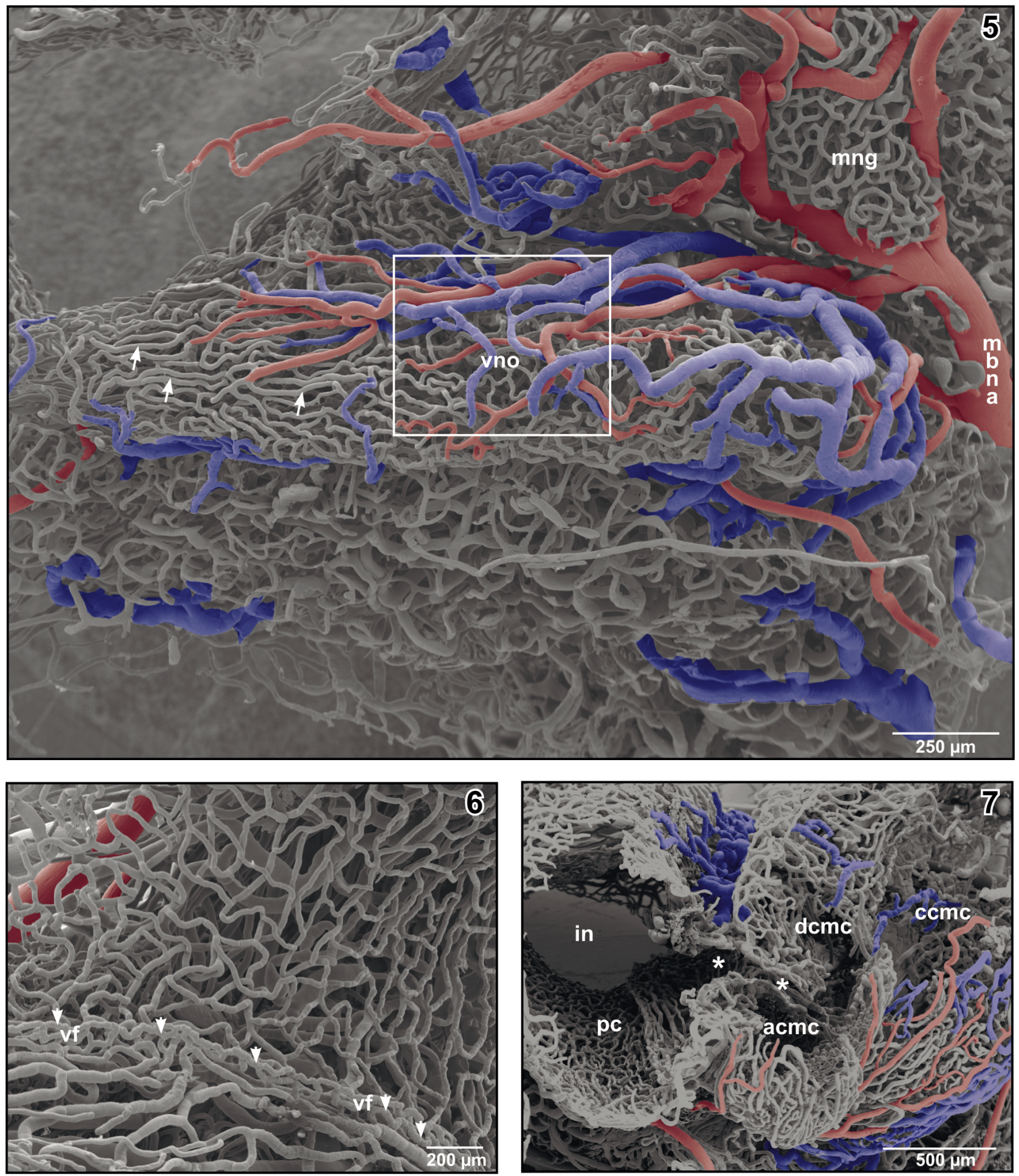

Fig. 5. Arterial supply and venous drainage of the vomeronasal organ (vno). Ventral view. Anterior is at top, medial is at right. Note the long slender capillary meshes at the lateral half of the vomeronasal organ (arrows). mbna medial branch of nasal artery, mng medial nasal glands.

Fig. 6. Capillary pattern at the ventral and medial walls of the principal chamber. Luminal view. Note the small capillary meshes of the ventral fold (vf) (arrowheads).

Fig. 7. Slit-like connection (asterisks) between principal chamber (pc) and anterior cavity of the middle chamber (acmc). Frontal view. Medial is at left, dorsal is top. demc dorsal cavity of middle chamber, ccmc caudal cavity of middle chamber, in inner naris (choana). 



Fig. 8. Capillary pattern of the anterior cavity of the middle chamber. Luminal view. Note the longitudinally arranged, densely packed capillary loops with dilated tips (arrowheads) at the bottom and the flat capillary network at the lateral wall (arrows). Inset. Capillary loop with arterial feeder (arrow). Note the dilated capillary tips (arrowheads).

Fig. 9. Arterial supply of capillary loops (arrows) of the vomeronasal organ epithelium. Abluminal aspect. Detail from Fig. 5 (enboxed area).

Fig. 10. Microvascular anatomy of the vomeronasal organ (vno). Luminal view. Same as Fig. 5, but vascular bed of the ventral olfactory epithelium is removed. Note one vein (v) draining several capillary loops extending towards the lumen of the vomeronasal organ (arrowheads). lng lateral nasal gland, mbna medial branch of nasal artery, mc middle chamber, mng medial nasal glands. 

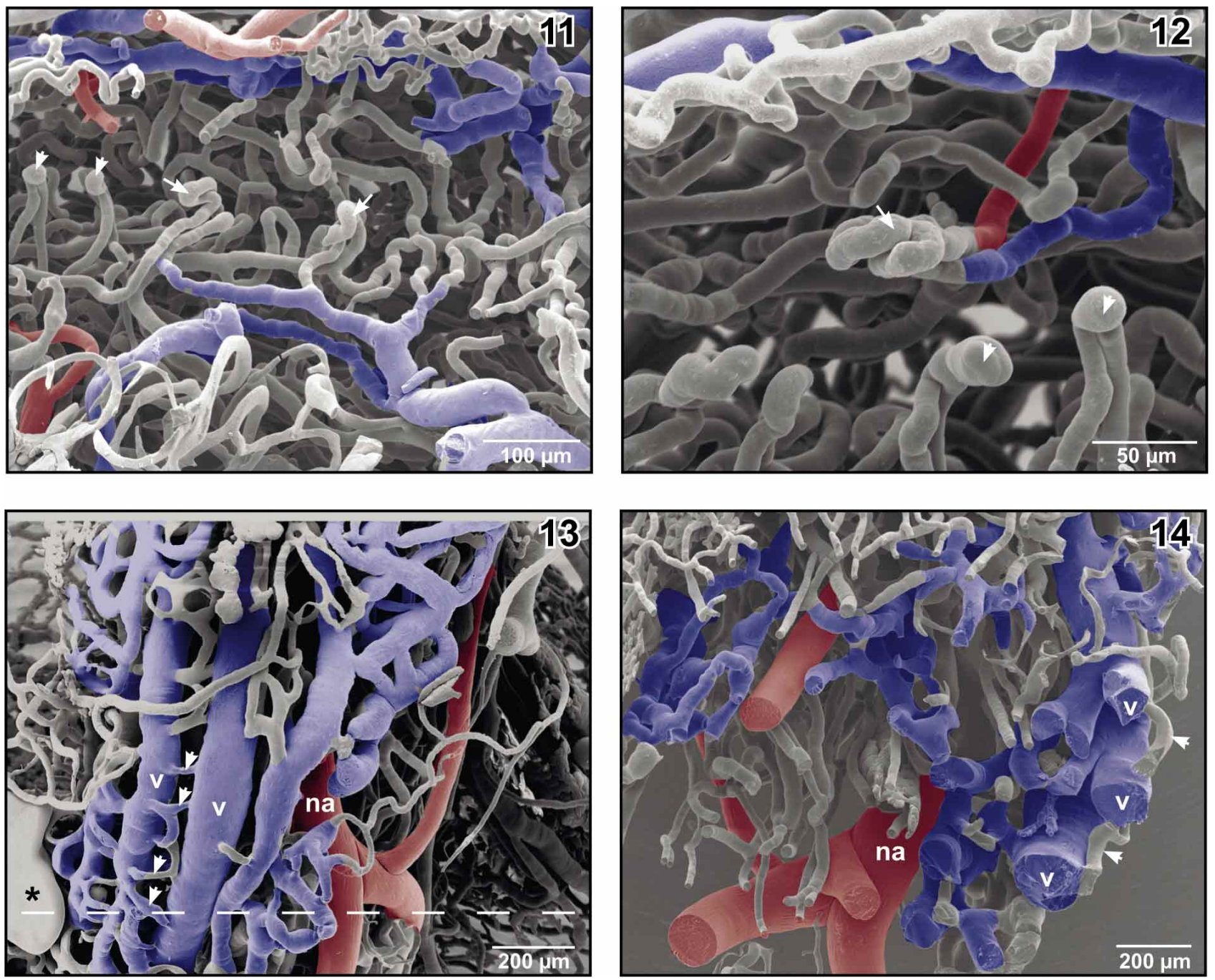

Fig. 11. Capillary pattern of the vomeronasal organ epithelium. Luminal view. Detail from Fig. 10 (enboxed area). Note simple capillary loops with rather straight ascending and descending (arrowheads) and coiled or twisted limbs (arrows).

Fig. 12. Two simple capillary loops (arrowheads) aside a capillary loop displaying double-twisted limbs (arrow) of the vomeronasal organ olfactory epithelium.

Fig. 13. Microvascular bed of the olfactory nerve. Ventral aspect. Note the parallel running large veins (v) interconnected by short capillaries (arrowheads). na nasal artery. Asterisk marks an evasate.

Fig. 14. Microvascular anatomy of the olfactory nerve. Transverse section at the level indicated in Fig. 13 (dashed line). Note capillaries interconnecting the parallel running veins (v)(arrowheads).

If a vascular pumping mechanism which assists influx and efflux from the VNO in a manner described in the VNO of some mammalian species (Schneider et al.; Salazar et al., 2008; Kondoh et al.) also exists in amphibians cannot be answered yet. The location of the VNO between part of the alary cartilage (rostrally) and the caudal portion of the strongly vascularized caudal portion of medial nasal glands (caudally) in combination with the given vascular anatomy of the VNO establish a structural prerequisite of such a vascular pumping mechanism. In this respect the vascular pattern found in the posterior group of nasal glands with parallel running large veins interconnected in a step-ladderlike pattern by thin short capillaries (Figs. 13 and 14) is of interest. These capillaries form veno-venous anastomoses and in case of an increased venous return, most likely will balance venous pressures within vessels. As the nature of the innervation of the blood vessels of the anuran VNO and its surroundings is not studied yet, the existence of a functional vascular pumping mechanism in amphibians still remains open for future investigations. 
LAMETSCHWANDTNER A. \& MINNICH B. Anatomía microvascular de órganos olfatorios y accesorios (vomeronasal) en adultos Xenopus laevis: Microscopía electrónica de barrido de moldes de corrosión vascular. Int. J. Morphol., 36(3):1007-1015, 2018.

RESUMEN: Se estudiaron la anatomía microvascular e histomorfología de los órganos olfatorios y vomeronasales de Xenopus laevis Daudin adultos, mediante microscopía electrónica de barrido de moldes de corrosión vascular y secciones de tejido seriadas, teñidas e incluídas en paraplast. Los resultados muestran que el suministro arterial es bilateral por arteriolas terminales de la rama medial de la arteria nasal y por la arteria palatina. Las arteriolas dan lugar a un lecho capilar característico de las superficies respiratorias en las cámaras principales y en las áreas dorsal y caudal de las cámaras intermedias. Las áreas anterior e inferior de las cámaras centrales poseen una red capilar significativamente diferente con llamativos bucles capilares cortos. Los bucles tienen una punta dilatada y se extienden en ángulos agudos hacia la luz de la cámara. El órgano vomeronasal (VNO) se ubica debajo del órgano olfatorio. Se extiende de medial a lateral y se une con su circunferencia caudal a las glándulas nasales mediales. El lecho capilar muestra mallas rectangulares que se orientan preferentemente a lo largo del eje longitudinal del VNO. Localmente, los capilares forman bucles cortos en forma de horquilla o fuertemente retorcidos con puntas dilatadas que apuntan hacia la luz del VNO. Estos capilares ralentizan la velocidad de la sangre y pueden conducir a un mayor intercambio de oxígeno, nutrientes y odorizantes, a base de agua en las cámaras intermedias y de feromonas, en el VNO. En este último, están presentes estructuras vasculares que podrían servir como una bomba vascular.

PALABRAS CLAVE: Xenopus; Órganos olfatorios; Microvasculatura; Moldes de corrosión vascular; Microscopía electrónica de barrido.

\section{REFERENCES}

Adam, H. \& Czihak, G. Arbeitsmethoden der Makroskopischen und Mikroskopischen Anatomie. Stuttgart, Fischer Verlag, 1964.

Aharinejad, S.H. \& Lametschwandtner, A. Microvascular Corrosion Casting in Scanning Electron Microscopy. Wien, Springer Verlag, 1992.

Altner, H. Untersuchungen über Leistungen und Bau der Nase des südafrikanischen Krallenfrosches Xenopus laevis (Daudin, 1803). Z. Vergl. Physiol., 45(3):272-306, 1962.

Eccles, R. Autonomic innervation of the vomeronasal organ of the cat. Physiol. Behav., 28(6):1011-5, 1982

Föske, H. Das Geruchsorgan von Xenopus laevis. Z. Anat. Entwicklungsgesch., 103:519-50, 1934.

Freitag, J.; Krieger, J.; Strotmann, J. \& Breer, H. Two classes of olfactory receptors in Xenopus laevis. Neuron, 15(6):1383-92, 1995.

Jermakowicz, W. J. 3rd.; Dorsey, D. A.; Brown, A. L.; Wojciechowski, K.; Giscombe, C. L.; Graves, B. M., Summers, C. H. \& Ten Eyck, G. R. Development of the nasal chemosensory organs in two terrestrial anurans: the directly developing frog, Eleutherodactylus coqui (Anura:Leptodactylidae), and the metamorphosing toad, Bufo americanus (Anura: Bufonidae). J. Morphol., 261(2):225-48, 2004.

Kondoh, D.; Nakamura, K. G.; Ono, Y. S.; Yuhara, K.; Bando, G.; Watanabe, K.; Horiuchi, N.; Kobayashi, Y.; Sasaki, M. \& Kitamura, N. Histological features of the vomeronasal organ in the giraffe, Giraffa camelopardalis. Microsc. Res. Tech., 80(6):652-6, 2017.
Královec, K.; Záková, P. \& Muzáková, V. Development of the olfactory and vomeronasal organs in Discoglossus pictus (Discoglossidae, Anura). J. Morphol., 274(1):24-34, 2013.

Lametschwandtner, A.; Lametschwandtner, U. \& Weiger, T. Scanning electron microscopy of vascular corrosion casts--technique and applications: updated review. Scanning Microsc., 4(4):889-940, 1990.

Lametschwandtner, A.; Miodonski, A. \& Simonsberger, P. On the prevention of specimen charging in scanning electron microscopy of vascular corrosion casts by attaching conductive bridges. Mikroskopie, 36(9-10):270-3, 1980.

Meredith, M. \& O'Connell, R. J. Efferent control of stimulus access to the hamster vomeronasal organ. J. Physiol., 286:301-16, 1979.

Meredith, M.; Marques, D. M.; O'Connell, R. O. \& Stern, F. L. Vomeronasal pump: significance for male hamster sexual behavior. Science, 207(4436):1224-6, 1980.

Motta, P. M.; Murakami, T. \& Fujita, H. Scanning Electron Microscopy of Vascular Casts: Methods and Applications. London, Kluwer Academic Publishers, 1992.

Murakami, T. Application of the scanning electron microscope to the study of the fine distribution of the blood vessels. Arch. Histol. Jpn., 32(5):445-54, 1971.

Nowack, C. \& Wöhrmann-Repenning, A. New anatomical analyses suggest a pumping mechanism for the vomeronasal organ in anurans. Copeia, 2009(1):1-6, 2009.

Oikawa, T.; Suzuki, K.; Saito, T. R.; Takahashi, K. W. \& Taniguchi, K. Fine structure of three types of olfactory organs in Xenopus laevis. Anat. Rec., 252(2):301-10, 1998.

Quinzio, S. I. \& Reiss, J. O. The ontogeny of the olfactory system in ceratophryid frogs (Anura, Ceratophryidae). J. Morphol., 279(1):37-49, 2018.

Saito, S. \& Taniguchi, K. Expression patterns of glycoconjugates in the three distinctive olfactory pathways of the clawed frog, Xenopus laevis. J. Vet. Med. Sci., 62(2):153-9, 2000.

Salazar, I. \& Sánchez Quinteiro, P. Supporting tissue and vasculature of the mammalian vomeronasal organ: the rat as a model. Microsc. Res. Tech., 4l(6):492-505, 1998.

Salazar, I.; Sánchez Quinteiro, P.; Cifuentes, J. M.; Fernández, P. \& Lombardero, M. Distribution of the arterial supply to the vomeronasal organ in the cat. Anat. Rec., 247(1):129-36, 1997.

Salazar, I.; Sánchez-Quinteiro, P.; Alemañ, N. \& Prieto, D. Anatomical, immnunohistochemical and physiological characteristics of the vomeronasal vessels in cows and their possible role in vomeronasal reception. J. Anat., 212(5):686-96, 2008.

Schneider, N. Y.; Fletcher, T. P.; Shaw, G. \& Renfree, M. B. The vomeronasal organ of the tammar wallaby. J. Anat., 213(2):93-105, 2008.

Suzuki, K.; Taniguchi, K. \& Syuto, B. Characterization of olfactory receptor organs in Xenopus laevis Daudin. Anat. Rec., 255(4):420-7, 1999.

Wang, H.; Zhao, H.; Tai, F. \& Zhang, Y. Postembryonic development of the olfactory and vomeronasal organs in the frog Rana chensinensis. Zoolog. Sci., 25(5):503-8, 2008.

Corresponding author:

Prof. Dr. Alois Lametschwandtner

University of Salzburg

Department of Biosciences

Vascular and Performance Biology Research Group

Hellbrunnerstrasse 34

A-5020 Salzburg

AUSTRIA

Email: Alois.Lametschwandtner@sbg.ac.at

Received: 25-01-2018

Accepted: 05-03-2018 